\title{
Measuring Teachers' Competency in Determining Students' Satisfaction through Electronic Internet Survey Method
}

\author{
Zeplin Jiwa Husada Tarigan, I Nyoman Sutapa, Jenny Mochta, and Widjojo Suprapto
}

\begin{abstract}
Improving competency can be conducted through several ways, such as education, training and practical on the job training. This human resource bulding aims to develop the comprehensive quality, which includes personality aspects, mastery of knowledge and technology, and professionalism and competency. To measure teachers' performance through students'satisfaction, Balanced Score Card (BSC) is used. In this case, it is to measure students' satisfaction to teaching processes, which are determined by good teaching processes and teachers'competency. Teachers' competency is divided into three components: classroom management, teacher professional development, and academic mastery. The data for this research is based on the results of the questionnaire distribution through internet to the whole students of Faculty of Economic, Petra Christian University, on 139 various subject teaching classes. The analysis is using the linear regression analysis, and it is obtained that teacher professionalism development can bring satisfaction to students during the learning processes positive and significant with 0.248 . Classroom learning management contributes to the students' satisfaction as well positive and significant with 0.371 . Subject mastery, or academic mastery, is able to give satisfaction to students through learning processes positive and significant with 0.518. Simultanuously, all three variables can build up satisfaction to students, which are obtained from the survey using electronic internet method.
\end{abstract}

Index Terms-E-satisfaction, classroom management, teacher professionalism development, and academic mastery.

\section{INTRODUCTION}

Education is a conscious and well-planned effort to create an atmosphere of learning and learning process so that learners actively develop their self potential capability to have spiritual religiosity, self-control, personality, intelligence, noble character, as well as skills needed by him, society, and state. National education functions to develop the ability and to form the character of the citizens to become a civil society in order to create a dignified nation by developing the potential of learners to become human beings who believe in God the Almighty, and citizens who are noble healthy, knowledgeable, capable, creative, independent, democratic and responsible [1]. The world of education is expected to become the driving force which facilitates the character building, so that the members of the community have the awareness of living the nation harmoniously and

Manuscript received July 13, 2018; revised November 13, 2018.

The authors are with Petra Christian University, Surabaya, Indonesia (e-mail: zeplin@petra.ac.id, mantapa@petra.ac.id, jennymd@petra.ac.id, joe.suprapto@gmail.com). democratically by still paying attention to the foundations of the Republic of Indonesia and the mutually agreed social norms. Character building and character education become a necessity, as through both, students become smart with good character and manner, so that their existence as a member of society become more meaningful for both himself and society in general.

The educational index improvement in Indonesian educational institutions shapes the strategic plan for national education, that is the reconstruction of national education, as the government has already set strategic goals from 2005 to 2025: the actualization of intellectual and competitiveness for Indonesian people. To achieve this vision, the development of national education is divided into four stages: the first phase, 2005-2009, with the theme of capacity building and modernization; the second stage, 2010-2014, with the theme of service strengthening; the third stage, 2015-2019, with the theme of regional competitiveness; and the fourth stage, 2020-2025, with the theme of international competitiveness. Looking at the stages, the first two national education developments focus on the internal factor of the students, and the next two stages focus on the external factors [2].

In the education system, the concentration on quality is not solely the responsibility of schools and government; instead it is a synergy between the various components, including the community. Therefore, the society must be aware of quality, so it can contribute to quality improvement and always considers the quality in life. Good quality is obtained from schools where students have the achievements, both academic achievements and achievements in other fields (sports, music, etc.) and it will also create good graduates. Through excellent graduates, it can be traced back about the role of lecturers in the teaching and learning process in college. Several private Christian universities in East Java are applying an employee performance measurement by adopting Balanced Score Card system consisting of four perspectives, namely growth and learning, internal process, customer satisfaction, and financial [3]. The growth and learning perspective consists of the qualification of lecturers from their educational and academic position backgrounds. The internal process perspective consists of the percentage of on-time graduation and the accomplishment of proposed programs by the departments. The perspectives of customer satisfaction consist of the student satisfaction on teaching process by the lecturers and the lecturer's involvement in join researches which contributes to the satisfaction from the society. Finally, the financial perspective consists of the ability of lecturers to get grants or funds from external sources. 
The emphasis in this research is related to the internal teaching process that is focused on the lecturers giving impact to the students' satisfaction through their competency. Based on the Indonesian Law no.12 [4], the duties and responsibilities of universities are conducting education and teaching, conducting researches, and performing community services. Education and teaching is a conscious and planned effort to create an atmosphere of learning and learning process so that learners are actively developing their own potential. The quality of the graduates is reflected in the customer satisfaction, the active participation of management in the process of continuous quality improvement, and the understanding of each person to the specific responsibility on quality.

Education and teaching conducted by competent lecturers will provide the students with completeness and sufficiency. Each lecturer must have the qualified competence in education and teaching. Lecturers competence is the ability of lecturers to possess a collection of knowledge, behavior and skills to achieve learning and education objectives. Competency is a set of knowledge, skills, and behaviors that must be owned, experienced and mastered by teachers or lecturers in performing their professional duties. The competencies that must be possessed are pedagogic, personality, social, and professional competence [1].

The competence of teachers in language teaching in Turkey is determined by indicators of grammatical understanding, teaching skills, ability to communicate, understanding each student differently, knowing the curriculum, developing learning materials and others [5]. The teacher competencies expressed by Yu et al., [6] in technical education are indicated by, among others: the knowledge of engineering concepts, engineering skills, engineering disciplines knowledge, pedagogical engineering, attitude toward engineering, attitude toward teaching and integration of engineering with other subjects. The competencies of the teachers presented by Nasongkhla and Sujiva [7] include the ability to upgrade themselves, the ability to organize student learning and classroom management, the ability to analyze and conduct research. A research by Shahmohammadi [8] about the teaching competence of teachers is knowledge, communication skills, good behavior, good class management and attractive appearance. While a research conducted by Ilanlou and Zand [9] on teacher's teaching competence in general is the familiarity with the psychology in development and learning; the awareness building of learners and ability to do the learning process well; class management by understanding teaching methods and understanding how to control the learning process; and experts in evaluating learning; meanwhile the special competence of teachers consists of content mastery, providing learning materials in sequence, ability to organize content well, mastery in using the tools of practice, keeping records accurately and providing feed back to the students.

\section{LITERATURE REVIEW}

\section{A. Classroom Management}

Teaching and learning process involves two types of processes that run simultaneously: one is the internal process which the students have to experience, and two is the external process which is given by others consciously and deliberately to enforce possibilities and conditions for students to achieve changes in their behavior and to grow their characters. These two activities do not take place separately, but rather simultaneously so that there is an active communication interaction at the same time between learners and educators [4]. Similarly, the process of learning at universities is the interaction between students and educators and learning resources in a learning environment to manage student's self-behavior, interaction with other students, and engaging in teaching activities [10].

During the process of change experienced by learners, the student-centered interaction occurs in the four domains, which are called the cognitive domain, affective domain, psychomotor domain, and cooperative domain. The cognitive domain talks about the ability to be acquainted with knowledge, reasoning or thinking; while the affective domain is the ability to prioritize the feelings, emotions, and different reactions based on reasoning, such as acceptance of the material, the participation of learners, determining the attitude of learners. The psychomotor domain is the ability to prioritize the physical skills, such as creativity; and the cooperative domain is the ability of learners to cooperate.

The classroom learning process consists of several components, such as lecturers, students, learning objectives, learning materials, and learning methods. The lecturers determine mostly the successful implementation of learning strategies. The ability of lecturers to manage classroom learning is observed through building students' behavior by utilizing teaching time, motivating learners, and building a communicative environment [11]. The classroom management describes an action by educators to create an environment and facility so that the process of academic learning and social interaction and emotions run well [12]. The indicators used to measure the learning process are the lecturers' ability to organize the learning activities, including facilitating activities by using learning methods that vary in accordance to the objectives and units of learning events; the lecturer ability to communicate the learning materials clearly; and the lecturer's enthusiasm in teaching.

\section{B. Teacher Professional Development}

The professionalism of a lecturer is reflected by the qualifications and performance that are proven by the mastery of academic knowledge, personality, social, and professional competence as a unity. The lecturers are always required to maintain and develop their professionalism in their field of expertise and possessed knowledge, as well as to understand and improve student's satisfaction. Professionalism must be owned by all lecturers to carry out their teaching tasks and build an academic atmosphere that makes conducive lecturer and student relationships. Universities are obliged to create a system that seeks to develop proficiency of the lecturers. The relationship between educators and learners can optimize the potential of learners, learning access, and motivation improvement learners [12]. The indicators used to measure include lecturers inspiring and motivating students to keep on 
growing their potent, lecturers' openness in interacting with students inside or outside the classroom setting, and lecturers showing discipline in utilizing the allocated teaching time.

\section{Academic Mastery}

The mastery of academic atmosphere for lecturers is a condition built by lecturers to cultivate the spirit of academic interaction between students, lecturers, education staff, and outsiders to improve the quality of academic activities, inside and outside the classroom. A good academic atmosphere is demonstrated by behaviors that prioritize the scientific truth, professionalism, academic freedom and consistent application of academic ethics. Evaluation of learning outcomes covers all aspects of learning and is conducted objectively, transparently and accountably by using valid and reliable instruments, and using benchmark reference assessments. Evaluation of learning outcomes functions to measure student academic achievement and provides input on the effectiveness of the learning process. Improved ability can provide a positive image for the training given by the coach to the athletes, in order to be able to face the challenge [13]. Theoretically, the mastery of learning by students is obtained through the skills and knowledge by teachers to achieve predetermined learning objectives [14]. Several Christian universities in Surabaya are measuring their academic mastery using two indicators: positive feedback from students and lecturers' expertise knowledge that can relate the teaching materials to other relevant topics.

\section{Students e-Satisfaction}

The organization should monitor the customer perception, in this case the level of expectation in which student's needs and expectations have been fulfilled. The organization shall determine the method for obtaining, monitoring and reviewing information. Students will be satisfied with the teacher if they are able to acquire new knowledge, new concepts, comprehend new problems well as new managerial experiences are obtained [15]. Student satisfaction is measured from the overall satisfaction of students to the teachers in conjunction with the interaction inside and outside the classroom. One particular university performs this student satisfaction measurement every semester, the student can only see the final grade after they have filled the satisfaction evaluation questionnaire of their lecturer. E-satisfaction students are students' satisfaction with the teaching of lecturers in the class by filling out questionnaires through the official campus website.

\section{HYPOTHESIS RESEARCH}

The quality learning is a process that is done both ethically and responsibly to ensure that every student can learn and enjoy learning. Quality learning occurs when teachers understand and enthusiastically interact positively with students where learning and experiences are well managed, and provide opportunities for students to produce the best. Lecturers as educators should be able to inspire their students to be individually independent so the students can motivate themselves to explore their subject matters. The lecturers are one of the resources that play a role in determining the teaching and learning process and the student achievement which is reflected from the quality of the universities. Meanwhile, the learning process planning includes syllabus and implementation plan that contains at least the purpose of learning, teaching materials, teaching methods, learning resources, and assessment of learning outcomes.

Teacher's competencies consist of innovation on development, thinking ability and problem solving, communication skills, continuous learning, leadership skills, team work and good ethics, and professional work [16]. Based on the statements, the competency of teachers is focused on the learning system that will impact on student satisfaction. The learning system is the classroom management, the teacher professional development, and the academic mastery. Based on the explanation above, the research hypotheses are constructed as follows:

H1: Good classroom management will bring impact to faculty student satisfaction

$\mathrm{H} 2$ : Adequate teacher professional development will bring impact to faculty student satisfaction

H3: Adequate academic mastery will bring impact to faculty student satisfaction

\section{RESEARCH METHOD}

The approach of this research is giving the meaning for each variable and seeking the relationship between variables based on the measurement scale. The type of research used in this research is to explain the influence between variables through hypothesis testing. The data collection technique is using questionnaires distributed to the students of Faculty of Economics in Petra Christian University from 139 active classes with total number of 2672 students. The questionnaire is designed with closed answers that mean the question is made in such a way that the respondents are limited in giving answers to some alternatives only or to one given answer only. To test the hypotheses, the multiple linear regression analysis is used. The multiple linear regression analysis measures the influence of more than one predictor variable (independent variable) i.e. classroom management, teacher professional development, and academic mastery to the dependent variable i.e. students' satisfaction. The purpose of multiple linear regression analysis is to measure the intensity of the relationship between two or more variables and to make an approximate prediction.

\section{DATA ANALYSIS}

For the data analysis, multiple linear regression analysis is used with the help of SPSS software. The Path analysis is illustrated in the form of hypothesis by describing the relationship between the independent variables and the dependent variables. The hypothesis testing to examine the influence of the classroom management variables, the teacher professional development, and the academic mastery simultaneously to the students' satisfaction is obtained from the value of the F-test.

Based on the results shown in the Table I above, the value of sig. is 0.000 , which is below 0.05 , so it can be said that the 
variables of the classroom management, the teacher professional development, and the academic mastery have positive and significant impact on students' satisfaction. Partial testing to determine each independent variable in the regression model (classroom management, teacher professional development, and academic mastery) having partial or individual impacts on students' satisfaction is performed by t-test (shown in Table II). This research states that the quality teaching system provided by the Faculty of Economics is able to deliver faculty students' satisfaction. This study is in line with the research of Shaltoni et al., [17] which states the provided quality system bringing impacts on faculty students' satisfaction. This research is also in line with Martirosyan [18], which states the education system related to faculty services, academic experience, student support facilities, campus life, and social integration bringing influence to students' satisfaction.

TABLE I: SiMULTANEOUS HYPOTHESES TESTING

\begin{tabular}{|c|c|c|c|c|c|c|}
\hline & $\begin{array}{l}\text { Sum of } \\
\text { Squares }\end{array}$ & df & Mean Square & $\mathrm{F}$ & \\
\hline & \multirow{3}{*}{$\begin{array}{ll}\text { Model } & \\
1 & \text { Regression } \\
& \text { Residual } \\
\end{array}$} & 14.708 & 3 & 4.903 & 482.020 & $.000^{a}$ \\
\hline & & 1.373 & 135 & .010 & & \\
\hline & & 16.081 & 138 & & & \\
\hline
\end{tabular}

TABLE II: PARTIAL HYPOTHESES TESTING

\begin{tabular}{|c|c|c|c|c|c|c|}
\hline \multirow[b]{2}{*}{ Model } & & \multicolumn{2}{|c|}{$\begin{array}{l}\text { Unstandardized } \\
\text { Coefficients }\end{array}$} & \multirow{2}{*}{$\begin{array}{c}\text { Standardized } \\
\text { coefficients } \\
\text { Beta } \\
\end{array}$} & \multirow[b]{2}{*}{$t$} & \multirow[b]{2}{*}{ Sig. } \\
\hline & & $\mathrm{B}$ & Std. Error & & & \\
\hline \multirow[t]{4}{*}{1} & (Constant) & -.413 & .108 & & -3.818 & .000 \\
\hline & Classroom Management & .371 & .070 & .352 & 5.260 & .000 \\
\hline & $\begin{array}{l}\text { Professional Teacher } \\
\text { Development }\end{array}$ & .248 & .059 & .237 & 4.210 & .000 \\
\hline & Academic Mastery & .518 & .090 & .402 & 5.786 & .000 \\
\hline
\end{tabular}

Based on Table II above, it can be inferred that the classroom management has a significance level of 0.000 , which is smaller than the level of significance 0.05 . Therefore, the classroom management has a positive and significant impact on the faculty students' satisfaction. In this case, the first hypothesis is acceptable. This research is in alignment with the research conducted by Martirosyan [18] which states the social interaction giving impacts to students' satisfaction. The study, however, differs from Liu research [19] which states the curriculum having no significant impact on the satisfaction of CAE (Cooperative Accounting Education) students with the Certified Public Accountant (CPA) firm internship.

The second hypothesis is accepted as the professional teacher development has a significant level of 0.000 , smaller than the 0.05 level of significance. It can be said that the professional teacher development has a positive and significant impact to faculty students' satisfaction. This study is in accordance with the research that states the professional teacher development bringing satisfaction by doing collaborative teaching with various universities [20].

The third hypothesis is accepted because the academic mastery has a significant level of 0.000 , which is smaller than the 0.05 significance level. It can be said that academic mastery has a positive and significant impact to faculty students' satisfaction. This research is in line with the research conducted by Martirosyan [18] which states the academic experience determining students' satisfaction. This study is also in line with the research by Petruzzellis [21] which states improvements in the teaching quality of the teachers providing an impact on faculty students' satisfaction. By knowing the value of variation of independent variables used in this model, it can explain the variation of dependent variable which is obtained from the value of the coefficient of determination.

TABEL III: THE COEFFICIENT OF DETERMINATION FOR THE FACULTY

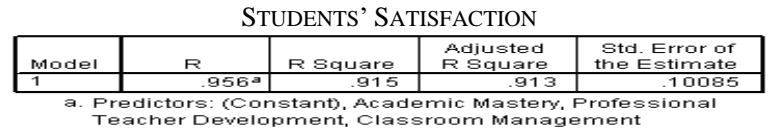

Based on the Coefficient Determination Table III, it is obtained that the value of $\mathrm{R}^{2}$ ( $\mathrm{R}$ Square) is 0.915 or $(91.5 \%)$. This shows that the percentage of independent variables of the classroom management, teacher professional development, and academic mastery is able to explain $91.5 \%$ variations of students' satisfaction variables, while the rest of $8.5 \%$ is influenced or explained by other variables which are not included in this research model.

\section{DISCUSSION AND CONCLUSION}

This research discusses the faculty students' satisfaction derived from the dimensions of the teacher's competency, which is observed from the classroom management, professional teacher development, and academic mastery. The result shows that the classroom management has a positive and significant impact on the faculty students' satisfaction. This is because the lecturers in the Faculty of Economics have been able to organize the learning activities well by giving the syllabus before the lecture begins, the reference books for the students, the lecture materials before the class starts, and facilitating the classroom activities using varied learning methods according to the learning objectives. The lecturers are able to communicate the learning materials clearly and enthusiastically. The result also shows that the professional teacher development has a positive and significant impact to the faculty students' satisfaction. This condition is caused by the lecturers' ability to inspire and motivate the students to keep developing, the lecturers' openness with the students by building a good rapport, the lecturers' willingness to interact with the students inside and outside the class through various gadget applications, and the lecturers' self-discipline in utilizing the teaching time allocation. Finally, the academic mastery brings a positive and significant impact to faculty students' satisfaction because some lecturers give a quick feedback from the test result, and the students are given three weeks to complain or protest about the exam result. Besides, the lecturers are very knowledgeable in their fields of study, and lecturers are able to connect the teaching concepts with other relevant topics. For future references, this research needs to investigate the effectiveness of lecturers' teaching in the classroom and the use of application technology in teaching.

\section{REFERENCES}

[1] Permenristekdikti Nomor 44 Tahun 2015 tentang Standar Nasional Pendidikan Tinggi. 
[2] M. Nuh, "Sambutan menteri pendidikan nasional pada rapat koordinasi penyusunan rencana aksi program," Direktur Jendral Pendidikan Tinggi, 2010,

[3] Z. J. H. Tarigan, I. N. Sutapa, and J. Mochtar, "A comparison of academic and non-Academic staffs' balanced score card based e-performance appraisal: A case study," in Proc. International Conference on E-Education, E-Business and E-Technology (ICEBT'17), July 2017, pp. 66-69.

[4] Undang-Undang Republik Indonesia tentang Pendidikan Tinggi no 12, 2012.

[5] Z. C. Karababa and G. Çalişkan, "Teacher competencies in teaching Turkish as a foreign Language," Procedia - Social and Behavioral Sciences, vol. 70, 2013, pp. 1545-1551.

[6] J. H. Yu, Y. Luo, Y. Sun, and J. Strobel, “A conceptual K-6 teacher competency model for teaching engineering," Procedia - Social and Behavioral Sciences, vol. 56, 2012, pp. 243-252.

[7] J. Nasongkhla and S. Sujiva, "Teacher competency development: teaching with tablet technology through classroom innovative action research (CIAR) coaching process," Procedia - Social and Behavioral Sciences, vol. 174, 2015, pp. 992-999.

[8] N. Shahmohammadi, "Competent teacher characters from students point of view," Procedia - Social and Behavioral Sciences, vol. 205, 2015, pp. 242-246.

[9] M. Ilanlou and M. Zand, "Professional competencies of teachers and the qualitative evaluation," Procedia - Social and Behavioral Sciences, vol. 29, 2011, pp.1143-1150.

[10] D. Gurcay, "Preservice physics teachers' beliefs regarding their teacher efficacy and classroom management," Procedia - Social and Behavioral Sciences, vol. 197, 2015, pp. 1101-1106.

[11] B. Gülbahar, "Opinions of lecturers regarding management of classrooms where Turkish is taught as a foreign language at an official Turkish teaching center," Procedia - Social and Behavioral Sciences, vol. 174, 2015, pp. 3120-3130.

[12] M. M. Popescu-Mitroi, L. L. Todorescu, and A. Greculescu, "Quality assurance and classroom management in the study of English in technical higher education," Procedia - Social and Behavioral Sciences, vol. 191, 2015, pp. 1917-1922.

[13] M. L. Quinton, J. Cumming, and S. E. Williams, "Investigating the mediating role of positive and negative mastery imagery ability," Psychology of Sport and Exercise, vol. 35, 2018, pp. 1-9.

[14] M. H. Amiruddin, N. A. Samad, and N. Othman, "An investigation effects of mastery learning strategy on entrepreneurship knowledge acquisition among aboriginal students," Procedia - Social and Behavioral Sciences, vol. 204, 2015, pp. 183-190.

[15] L. Rueda, J. Benitez, and J. Braojos, "From traditional education technologies to student satisfaction in management education: A theory of the role of social media applications," Information and Management vol. 54, 2017, pp. 1059-1071.

[16] K. Somprach, P. Popoonsak, and S. Sombatteera, "Soft skills development to enhance teachers' competencies in primary schools," Procedia - Social and Behavioral Sciences, vol. 112, 2014, pp. 842-846.

[17] A. M. Shaltoni, H. Khraim, A. Abuhamad, and M. Amer, "Exploring students' satisfaction with universities' portals in developing countries: A cultural perspective," The International Journal of Information and Learning Technology, vol. 32, no. 2, 2015, pp. 82-93.

[18] N. Martirosyan, "An examination of factors contributing to student satisfaction in Armenian higher education," International Journal of Educational Management, vol. 29, no. 2, 2015, pp. 177-191.

[19] G. Liu, "A survey on student satisfaction with cooperative accounting education based on CPA firm internships," Asian Review of Accounting, vol. 20 , no. 3 , 2012, pp. 259-277.
[20] D. Potolea and S. Toma, "The dynamic and multidimensional structure of the teachers professional development," Procedia - Social and Behavioral Sciences, vol. 180, 2015, pp. 113-118.

[21] L. Petruzzellis, A. M. D'Uggento, and S. Romanazzi, "Student satisfaction and quality of service in Italian universities," Managing Service Quality: An International Journal, vol. 16, no. 4, 2006, pp. 349-364.

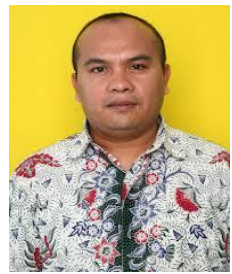

Zeplin Jiwa Husada Tarigan, was born in 1974. He obtained his bachelor degree in electric and telecommunication engineering, and master's degree in industrial management from Sepuluh Nopember Institute of Technology. He obtained his doctorate degree from University of Brawijaya, Malang, Indonesia. He has experienced as a manager in PPIC and BPO PP SAP R/3 in some manufacturing industries. At the moment, he is a full time faculty member at Petra Christian University, teaching in the program magister management or master's program. His research interests are ERP and operation management.

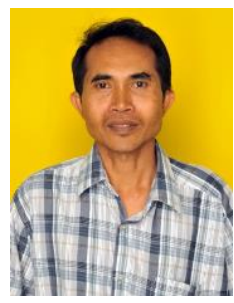

I N. Sutapa was born in Bali, Indonesia in 1968. He graduated from industrial mathematics of Universitaet Kaiserslautern, Germany and the doctorate of operation management from Brawijaya University, Malang, Indonesia. He is a full-time lecturer in the Industrial Engineering Department, Petra Christian University Surabaya Indonesia since 1993. The courses he teaches range from calculus, operationa research, lean manufacturing, quality management system, and performance management. His research interest is the mathematical model for inventory, supply chain, and decision making, performance measurement system, and quality improvement.

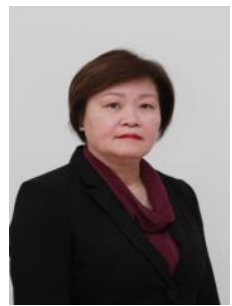

Jenny Mochtar is a full-time lecturer in the English Department of Petra Christian University. She obtained her MA in Literature from Arizona State University and her Doctorate degree from the University of Indonesia. She was the head for the Office of Quality Assurance for two periods and is currently the Vice Rector for Academic Affairs of Petra Christian University. She gives trainings in implementing Quality Assurance for Indonesian Higher Education Her research interest lies in designing internal quality assurance system and the implementation of QA in Indonesian Higher Education. Her recent research is in BSC based reward system for higher education.

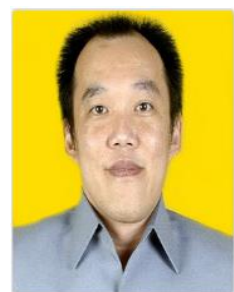

Widjojo Suprapto was born in 1967 . He obtained his bachelor degree in English literature from Petra Christian University, Surabaya, Indonesia, and his master's degree in hospitality management from University of Nevada Las Vegas, USA. He devotes his experiences in the world of tourism, hotel, and restaurant. He is also a full time faculty member in Petra Christian University, Surabaya, Indonesia, teaching in the business management program. His research interests are hospitality supply chain management and Chinese family business. 